\title{
STUDIES ON THE CARDIOVASCULAR ACTIONS OF CHLORPROMAZINE
}

\author{
III. EFFECTS ON CEREBRAL BLOOD FLOW, BLOOD PRESSURE, \\ AND ELECTROCORTICOGRAM, AS RECORDED SIMULTANEOUSLY ${ }^{1}$
}

\section{A Romagnoli and K I. Melville ${ }^{2}$}

ALthough CHLORPROMAzine is primarly employed as a central nervous system depressant drug, Lehmann and Hanrahan (1) early reported convulsive seizures as a side-effect of therapy in psychiatric patients. Using the. "cerveau isolé," Das, Dasgupta and Werner (2) also observed increased electrical activity following injectıons of the drug Indeed, in one case of chlorpromazine poisoning definite convulsions have been reported (3). Schlichther et al (4) have also moie recently stated that as high as 52.4 per cent of the patıents under intensive chlorpromazine therapy show convulsive seizures.

Preston (5), using cats, recorded both depression and stimulation of the central nervous system function, and suggested that "chlorpromazine is a neuronal stimulant and that the amygdala is particularly sensitive to this drug" Indeed, this author postulates that the "tranquillizing" effects of chlorpromazine might be due to the increased electrical actinity of the amygdala.

Berger et al (6) have reported that in curarized cats artificially respired recordings of electrical changes from cortical and intercortical structures showed that "chlorpromazine at a dose of 1 to $15 \mathrm{mg} / \mathrm{kg}$ produced irregular slowing in the cerebral cortex, with outbursts of 7 to $10 \mathrm{cycles} / \mathrm{sec}$ of activity and occasionally slow waves of 2 to 3 cycles/sec." Margohs (7) has also concluded that in man "convulsions are far from uncommon in intensive chlorpromazine therapy."

On the contrary, Winkelman (8) observed that chlorpromazıne potentrates the sedative actions of ant1-convulsant drugs, and Goldman (9) could observe no evidence of seizures in 500 patients receiving up to $24 \mathrm{gm}$ darly Kelly and Lawrence (10) have also reported that chlorpromazine decreases seizures in clinical and experimental tetanus, and Thibault (11) treated successfully a patient with severe postoperative convulsions with the so-called "lytic cocktail"

Lehmann has further postulated that the convulsions observed after chlorpromazine might be due to hypoxia of the brain following syncopal attacks due to orthostatic hypotension (12), but the problem has, been somewhat obscured by the fact that in some patients it was noted that there had been a previous history of convulsive seizures ( 1 ).

In view of the above observations and in connection with other studies in this laboratory concerning the general cardıovascular actions of chlorpromazine $(13,14)$ it was of interest to investigate its influence upon the cerebral blood flow, blood pressure and associated electrocorticogram, as recorded simultaneously.

1Supported in part by grants from Poulenc Ltd, Montreal

2Department of Pharmacology McGill University, Montreal, P Q 
In connection with these studies a number of similar experiments were also performed using diethazine (Diparcol). Jenkner and Lechner (16) have reported that the electrical abnormalities associated with cerebral trauma were normalized by administration of Diparcol. There are no other studies in the literature on this question so far as we are aware.

\section{MethoDS}

Dogs were used. In general, the animals were first etherized and artificial respiration instituted and maintained throughout all the experiments. The operative procedure consisted of a mid-line incision extending from the base of the nose to the occipital protuberance. The juncture of the sagittal and coronal sutures was exposed. Three small ( $4 \mathrm{~mm}$. diameter) holes were trephined in the skull in such a manner as to form a triangular area, the middle of which was located approximately $1 \mathrm{~cm}$. lateral and $1 \mathrm{~cm}$. posterior, to the previously identified junction of the sutures. After this procedure was completed, the animals were curarized with succinylcholine $\left(1 \mathrm{mg}\right.$./ $\mathrm{cc}_{\text {. }}$ ) by continuous intravenous drip, the total dose ranging from $200 \mathrm{mg}$. to $500 \mathrm{mg}$. The cerebral blood flow (C.B.F.) was measured by ${ }^{\circ}$ an indirect method, using the principle described by Ludwig (15) modified to record the temperature changes, after suitable calibration. A diagram of the electrical arrangement employed is shown in Figure 1. The

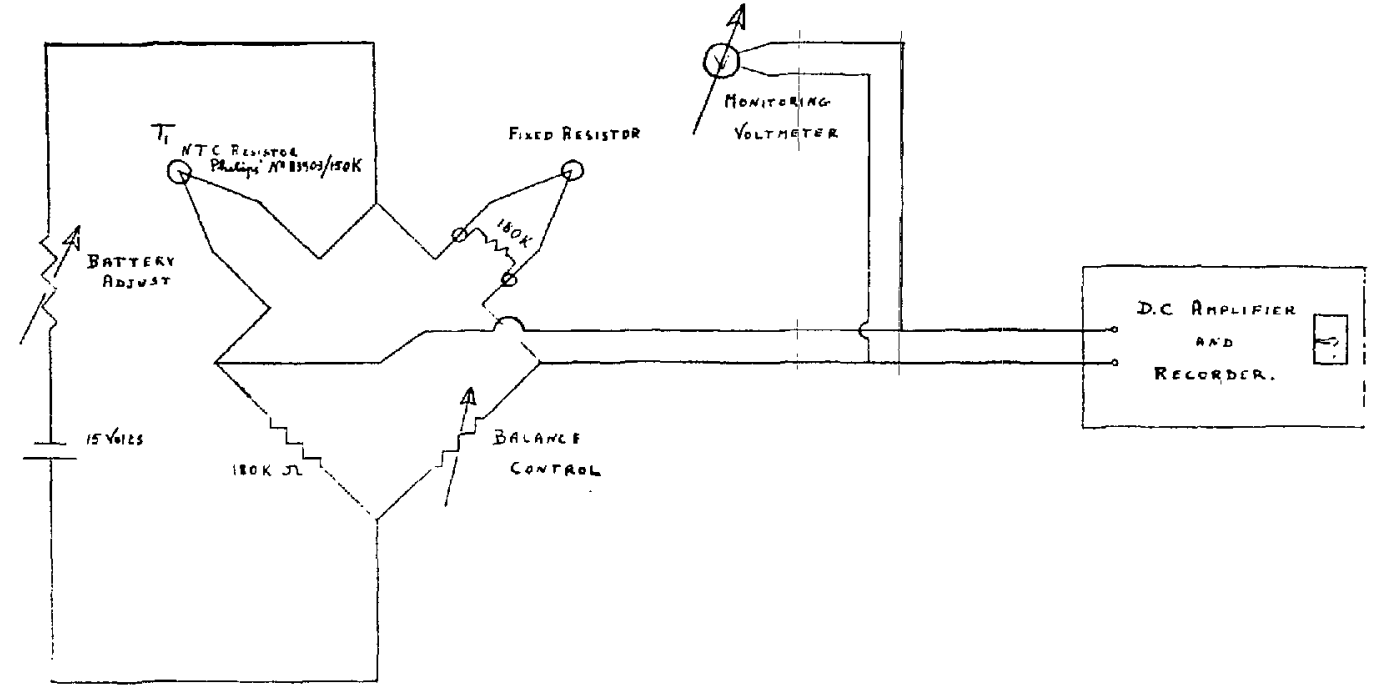

Figure 1. Diagram of bridge for measuring temperature variations due to changes in the cerebral blood flow (C.B.F.). The output of the bridge varies with the temperature at $T_{1}$, as recorded by the N.T.C. Resistor.

temperature changes of the underlying cerebral cortex are picked up by a N.T.C. Resistor. ${ }^{3}$ The tip of the resistor $(1 \mathrm{~mm}$. in diameter) was placed through the middle orifice in the skull and directly in contact with the exposed cerebral cortex of the lateral gyrus on the left side. The electrocorticogram, referred to as E.E.G., was recorded from the same area of the brain by two fine platinum electrodes

'Negative Temperature Coefficient Resistor kindly supplied by the N. V. Phillips' Gleeinlampenfabrieken, Eindoven, Netherlands. 
( $0.5 \mathrm{~mm}$. in diameter), inserted through the two orifices on either side of the resistor, approximately $1 \mathrm{~cm}$. apart-the tip of the electrodes being placed on the unopened dura mater, in order to avoid unnecessary damage to the brain and excessive leakage of the cerebrospinal fluid.
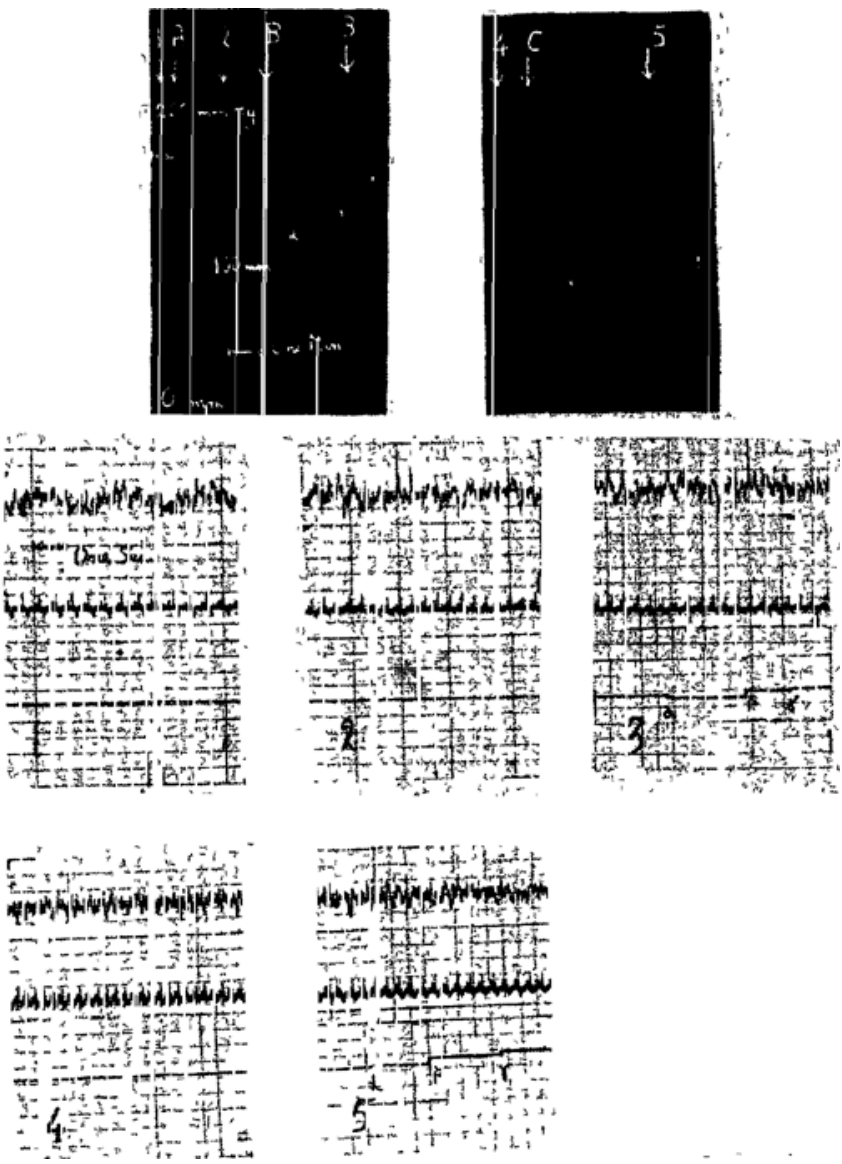

Figure 2. Dog, male, $14.0 \mathrm{~kg}$. Above, kvmographic blood pressure records-an interval of 10 minutes elapsed between each section, curng which an additional dose of $10 \mathrm{mg} . / \mathrm{kg}$. of chlorpromazine was injected At $A_{1}$ chlorpromazine $(5 \mathrm{mg} . / \mathrm{kg}$.) and at both $B$ and $\mathbf{C}$. chlorpromazine (10 mg./kg.) were mjected. Below, sections of E.E.G., E.C.G. and C.B.F. records taken at nos. 1 to 5 , as marked on the kymographic records-on nos. 3 and $5 \alpha, \beta$ and $\gamma$, corresponding to points so marked on the blood pressure record above.

Both the E.E.G. and C.B.F. changes were recorded continuously with a Sanborn Twin-Viso Cardiette. ${ }^{4}$ The blood flow recording apparatus was calibrated so that $1^{\circ} \mathrm{C}$. change in temperature produced an oscillation of $4 \mathrm{cr}$. on the recording paper. Electrocardiograms (Lead 11) were recorded simul:aneously on a sing e channel Viso-Clardiette (Sanborn) in most cases. The direct (femoral) blood pressure changes were also recorded kymographically. All animals were heparinized ( $1 \mathrm{mg} . / \mathrm{kg}$.), and all drugs were injected in an exposed femoral vein. Chlorpromazine hydrochloride (Largactil) in powder form ${ }^{5}$ was used, and solutions freshly made up as needed.

4The writers are indebted to Dr. John Feeney of St. Mary's Hospital, Montreal, for the loan of this instrument.

5Kindly supplied by Poulene Ltd, Montreal. 


\section{Results}

Figures 2 and 3 demonstrate some examples of the changes which were observed following repeated administrations of large doses of chlorpromazme ( 5 to $20 \mathrm{mg} / \mathrm{kg}$ ) Eight such experiments were performed

As can be seen in Figure 2 at $A$ and $B$ follownng injectron of 5 and $10 \mathrm{mg} / \mathrm{kg}$ respectrvely, of chlorpromazine, there was a transient intense fall in blood pressure associated with some slight increase in heart rate Concomitantly, the cerebral blood flow (CBF) (nos 2 and 3) showed a slight decrease, while there appeared to be relatively httle change on the E EG record Durng the interval between the two recordings a further dose of $10 \mathrm{mg} / \mathrm{kg}$ was given without much further change in the record, but a marked fall in blood pressure associated with an increase of the $\mathrm{C} \mathrm{B} \mathrm{F} \mathrm{Followng} \mathrm{a} \mathrm{third} \mathrm{similar} \mathrm{dose} \mathrm{of} \mathrm{the}$ drug (C) the C B F progressively increased as the fall in blood pressure persisted
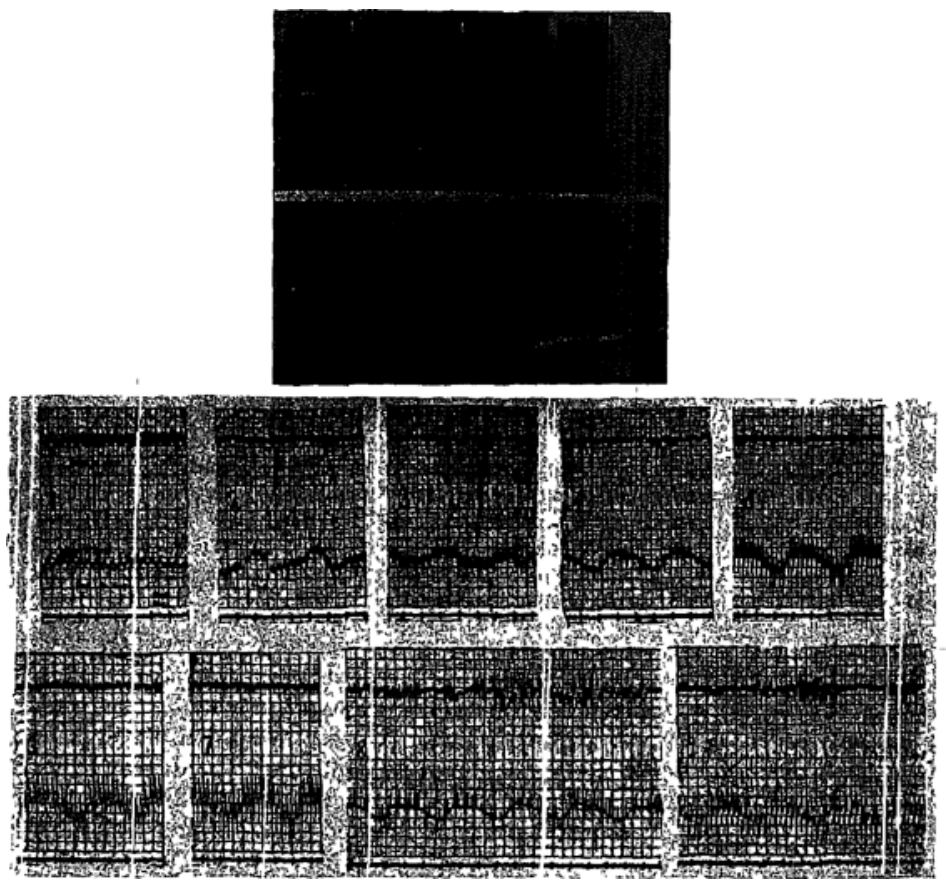

Figure $3 \mathrm{Jog}$, fenale, $86 \mathrm{~kg}(a)$ The upper and lower kymographic records are contunuatrons, and sections of $(b)$ the associated E EG (above) and E C G (below) records, taken at nos 1 to 9 , as marked on the kymographe tracings, are shown ATA, B and C, respectively, chlorpromazme $(10 \mathrm{mg} / \mathrm{kg})$ and at $\mathrm{D}$, chlorpromazine $(20 \mathrm{mg} / \mathrm{kg})$ were injected 
with no tendency to recovery The electrical activity at this point also showed some increase in both rate and voltage (nos 4 and 5)

Figure 3 shows agam sumlar depressor responses followng injections of chlorpromazine $\mathrm{A}, \mathrm{B}, \mathrm{C}$ and $\mathrm{D}$, but the changes in electrical activity are more strikngly seen Thus with the prolonged hypotension there is a progressive increase in heart rate, the E E G showing at first a progressive slowing of electrical actuvity, (nos 2 and 3 ), followed by an increase in fast electrical activity (nos 6 and 7), after the thrrd dose of the drug (C), as compared to the pre-injection period (5) It is to be noted that when a larger dose (D) was given, periods of striking electrical outbursts developed (no 8) and contunued intermittently thereafter (no 9)
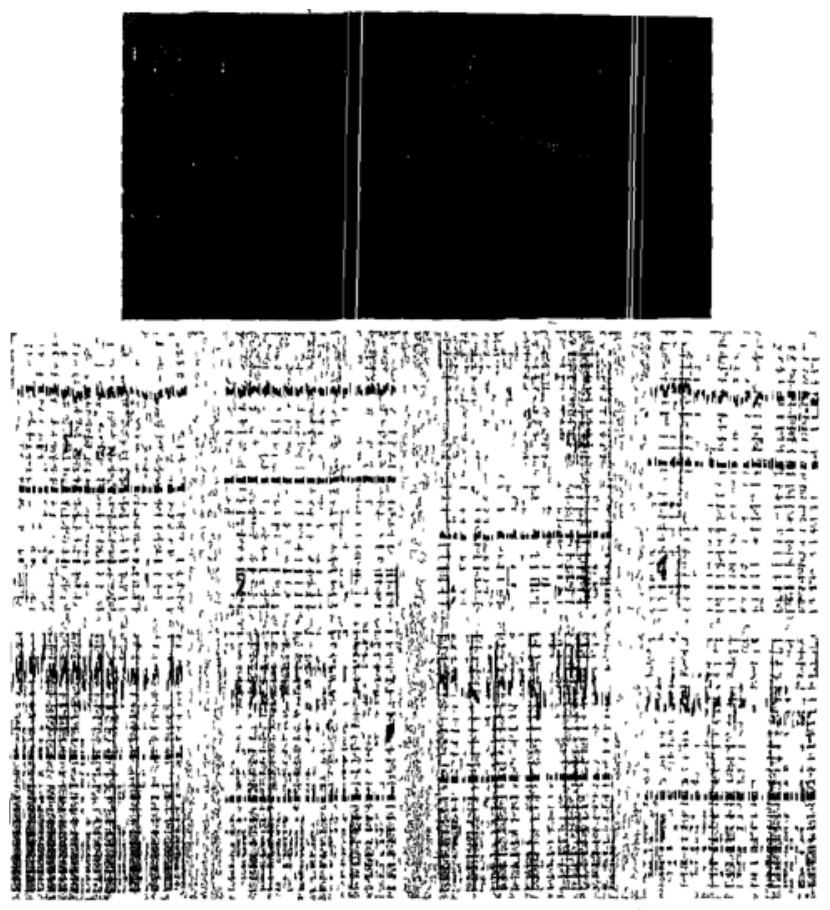

Figure 4 Dog, emale, $74 \mathrm{~kg}$ Kymographic record of blood pressure äbove and sections of associated E E C, E.CG and C B F records (below) taken at nos 1 to 8, as marked on the kymographic record, are shown The changes in CBF on nos $2,3,6$ and 8 , marked $a, \beta$ and $\gamma$ correspond to those shown on the blood pressure record At $A$ and $D$, respectuvely, 10 $\mathrm{mg} / \mathrm{kg}$, and at $B, 20 \mathrm{mg} / \mathrm{kg}$ of metrizol were mjected At $\mathrm{C}, 10 \mathrm{mg} / \mathrm{kg}$, and at E, 20 $\mathrm{mg} / \mathrm{kg}$, of chlorpromazine were given 
From the above findings it is evident that with prolonged and repeated admunstrations of high doses of chlorpromazine definte localized electrical outbursts can be observed under these conditions On the other hand, as indicated m many of the imital responses, a single mjection of the drug leads only to a decrease in cortical electrical activity

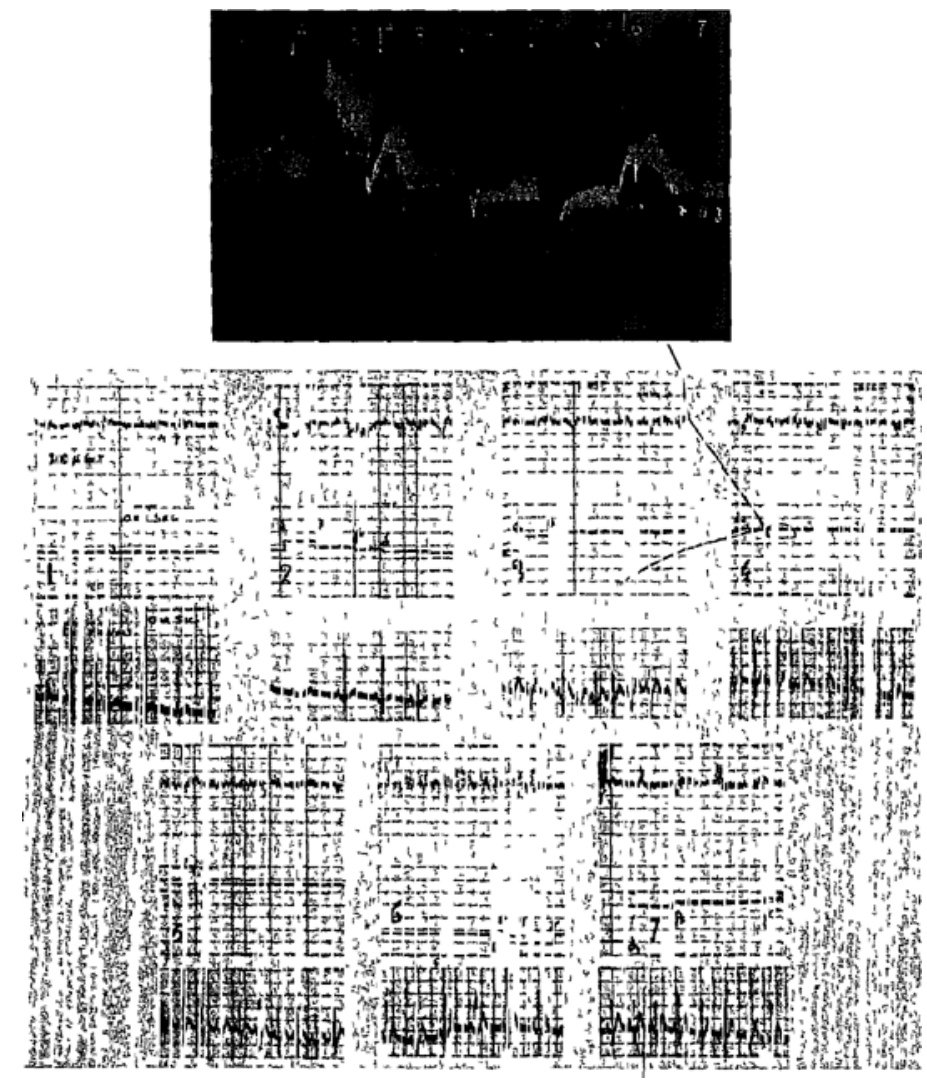

Fravose 5 Dog, male, $120 \mathrm{~kg}$ Morphunized $(10 \mathrm{mg} / \mathrm{kg}$ ) before anaesthesta Kymographic record of the blood pressure (above) and sectrons of associated E EG, C B F, and E C G records (below) taken at Nos 1 to 7 , as marked on the kymographic tracing, are shown. On nos $2,3,4,5,6$, and 7 the changes correspond to the points marked by $a, \beta$ and $\gamma$, on the record Between nos 5 and $B$ the $\mathrm{CB} \mathrm{F}$ recording stylus bad to be adjusted (lowered) in order to permit recordung, and start of record no 6 should therefore be considered as a direct contanuation of the end of no 5 At $A$ and $E$, metrazol $(10 \mathrm{mg} / \mathrm{kg})$, at $B$ and $D$, chlorpromazne $(10 \mathrm{mg} / \mathrm{kg})$ and at $\mathrm{C}$, adrenaln $(100 \mu \mathrm{gm})$ were adminstered 
In the second series of experinents it was of mterest to investigate the influences of chlorpromazine upon the responses to various central nervous system stmulants including metrazol, picrotoxm, nikethamide and methamphethamine Some typical effects of the responses to metrazol are shown in Figures 4 and 5

Following control injections of metrazol (A and B), one sees a rise in blood pressure associated whth a marked outburst of cortical strmulation (no 3) These effects were, however, accompaned by slowng of the heart and a considerable fall in the CBF The pre-mjection conditions were soon restored (no 4), whereupon mjection of chlorproma me (C) rapidly induced marked tachycardia with increased $\mathrm{E} \mathrm{EG}$ acturity and there was a slight increase in $\mathrm{CBF}$ although there was a marked fall in blood pressure

A subsequent injection (D) of metrazol (one-half of the dose previously employed at $B$ ) now induced a more intense and sustaned rise in blood pressure and stumulation in EEG actanty There was, however, no associated bradycardia and a rise rather than a fall in CB F The excessive electrical activity persisted for the remainder of the experiment and appeared to be somewhat intensified (no 8) by the mjection of a further large dose of chlorpromazine (E) Indeed, the EEG following chlorpromazne were now rather like those of metrazol, although the vascular changes were quite opposite Sumlar results were observed in 8 other similar experiments

Since it has been claumed that chlorpromazine can potentiate the central nervous sỳstem effects of analgesics, three simular expenments were performed on animals which were prevously morphtnized A typidal example of the findings is shown in Figure 5 As can be seen, under those conditons, the mitial injectron of metrazol (A) produces a good rise in blood pressure associated with moderate EEG stmulation and a bref norease in $C B F$, which, however, returned to normal whle the blood pressure was stll mantained (no 2) However, follownng chlorpromazine injection at $\mathrm{B}$ there was now only a moderate depressor response, associated with tachycardia, and a sustaned increase in C B.F, despite the fall in bload pressure (no 3)

Somewhat simular changes were observed following an injection of adrenalm

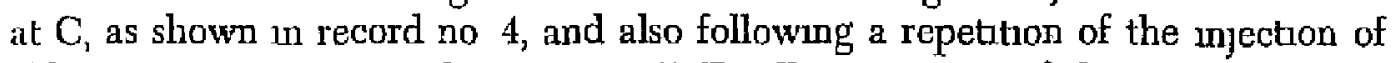
chlorpromazine, at $D$, as shown at ho 5 Finally, repetition of the metrazol injection at $\mathrm{E}$, although still inducing a pressor response, associated with the usual marked cortucal stmulaton (nos 6 and 7), there was an mittal decrease followed by an increase in the rate of the C B F It is therefore clear that chlorpromazine enhances the cortical stmulating action of metrazol, both in the non-morphini and morphtnized anmal under these condations, However, although metrazol mcreases blood pressure and reduces C B F, chlorpromazme leads to a fall in blood pressure and a marked morease in the $\mathrm{CBF}$ It is also noteworthy that although chlorpromazme blocks the pressor iesponse to unjected adrenaline, the rase in blood pressure produced by metrazol sall occurred However, in other experments in ron-morphinzed arumals, following a large dose $(20 \mathrm{mg} / \mathrm{kg})$ of chlorpromazine, the pressor response to metrazol was completely aboished although the cortacal stumulation was stll in evidence The observed pressor response to metrazol is therefore an adrenergic effect 
Somewhat sumlar results were also obtained in simular experments in which nukethamoude $(50 \mathrm{mg} / \mathrm{kg}$ ) was employed instead of metrazol Under these condrtions the cortical stimulation following nikethamde is not abolished by chlorpromazine, but the pressor response to the agent is reversed No observations were made on the C B F in this group of experiments
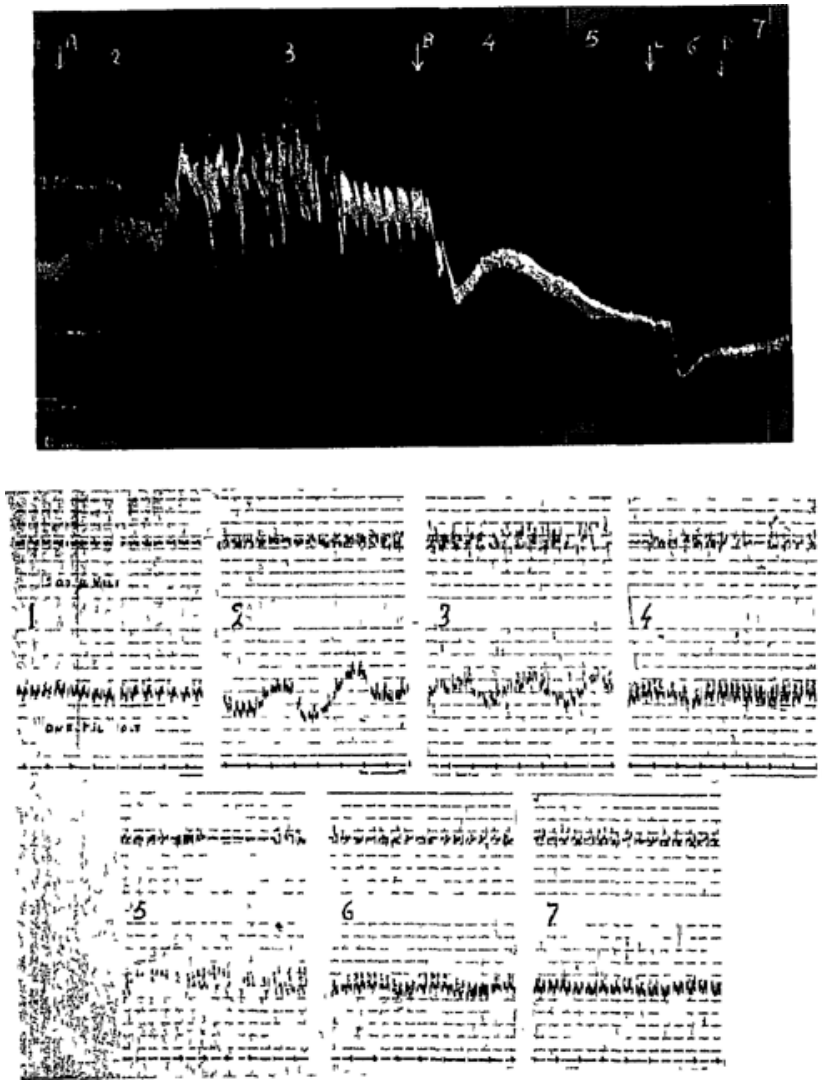

Frgure 6 Dog, male, $95 \mathrm{~kg}$ Kynographie record of blood pressure (above) and sections of associated EEG and ECG records (below), taken at nos 1 to 7 , as marked on the kymographuc tracing, are shown At A, pucrotoxu $(2 \mathrm{mg} / \mathrm{kg})$, at $B$ and $\mathrm{C}$, chlorpromazine (10 $\mathrm{mg} / \mathrm{kg})$, and at $\mathrm{D}$, picrotoxin $(1 \mathrm{mg} / \mathrm{kg})$ 
Figures 6 and 7 show typical examples of simular types of experiments in which the effects of chlorpromazme upon the responses to picrotoxin and methamphetamune were studied
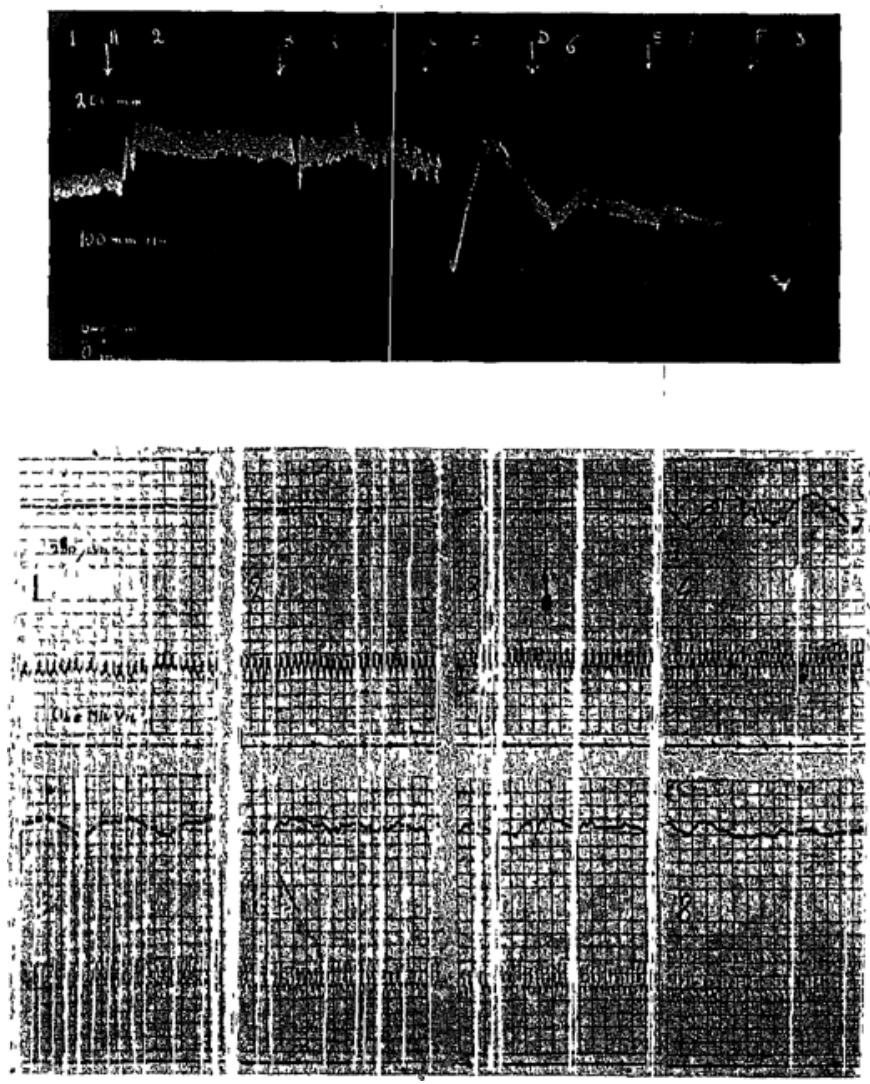

Figure 7 Dog, female, $142 \mathrm{~kg}$ Kymographic records of blood pressure and sechons of associated EEG and ECG records taken at nos 1 to 8 , as marked on the cymographuc tracings, are shown At $\mathrm{A}$ and $\mathrm{B}$, methamphetamine ( 1 and $2 \mathrm{mg} / \mathrm{kg}$, respectively), at $\mathrm{C}$, chlorpromazine ( $10 \mathrm{mg} / \mathrm{kg}$ ), at $\mathrm{D}$ and $\mathrm{E}$, metamphetamine (1 anc $2 \mathrm{mg} / \mathrm{kg}$, respectively) and at $\mathrm{F}$. adrenalin $(200 \mu \mathrm{gm})$ were injer ted 


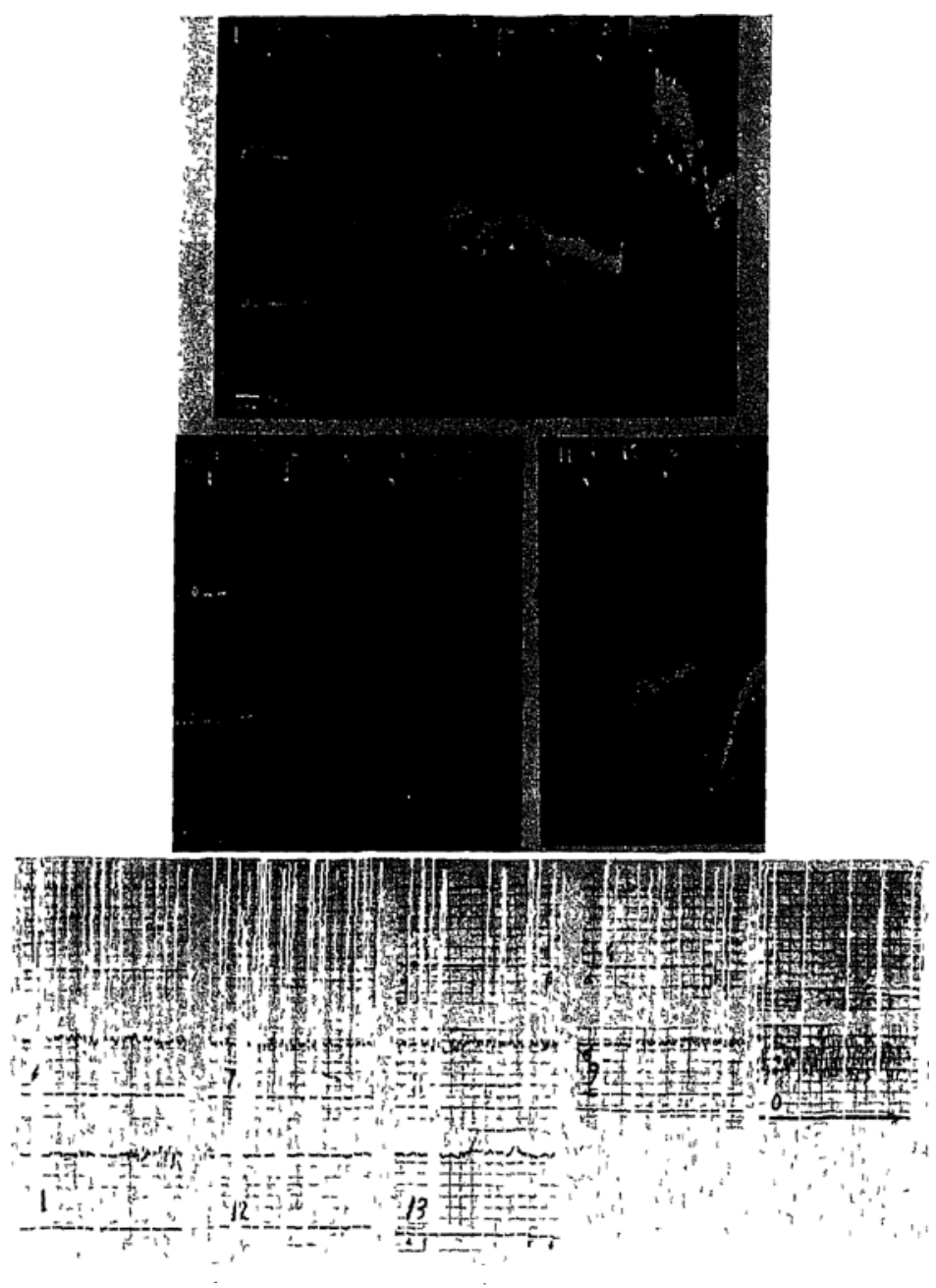

EXPLRIMENT I

FIGURe 8 Experiment I Dog, male, $94 \mathrm{hg}$ Kymogranphc record of blood pressure (above) and sectoons of associated $\mathrm{EEC}$ and $\mathrm{CBF}$ (below), tahen at nos $I$ to $I 3$, as shown on the kymograpluc records On nos $3,4,5$ and 13 the changes correspond to the points marked by $\alpha, \beta, \gamma$ and $\sigma$ An interval of 18 minutes elapsed between the upper and the lower records and in interval of 18 minutes elapsed between the two lower sectians At $A, D, E$, and $H$, metrazol (10 $\mathrm{mg} / \mathrm{kg}$ ), at $\mathrm{B}, \mathrm{C}$ and $\mathrm{F}$, ansolysen $(07,14$ and $10 \mathrm{mg} / \mathrm{kg}$, respectuvely), at $\mathrm{C}$ ind $\mathrm{J}$, chlorpromnzine ( $10 \mathrm{mg} / \mathrm{kg})$ and at $\mathrm{I}$, adrenalı $(100 \mu \mathrm{gm})$ were moected 


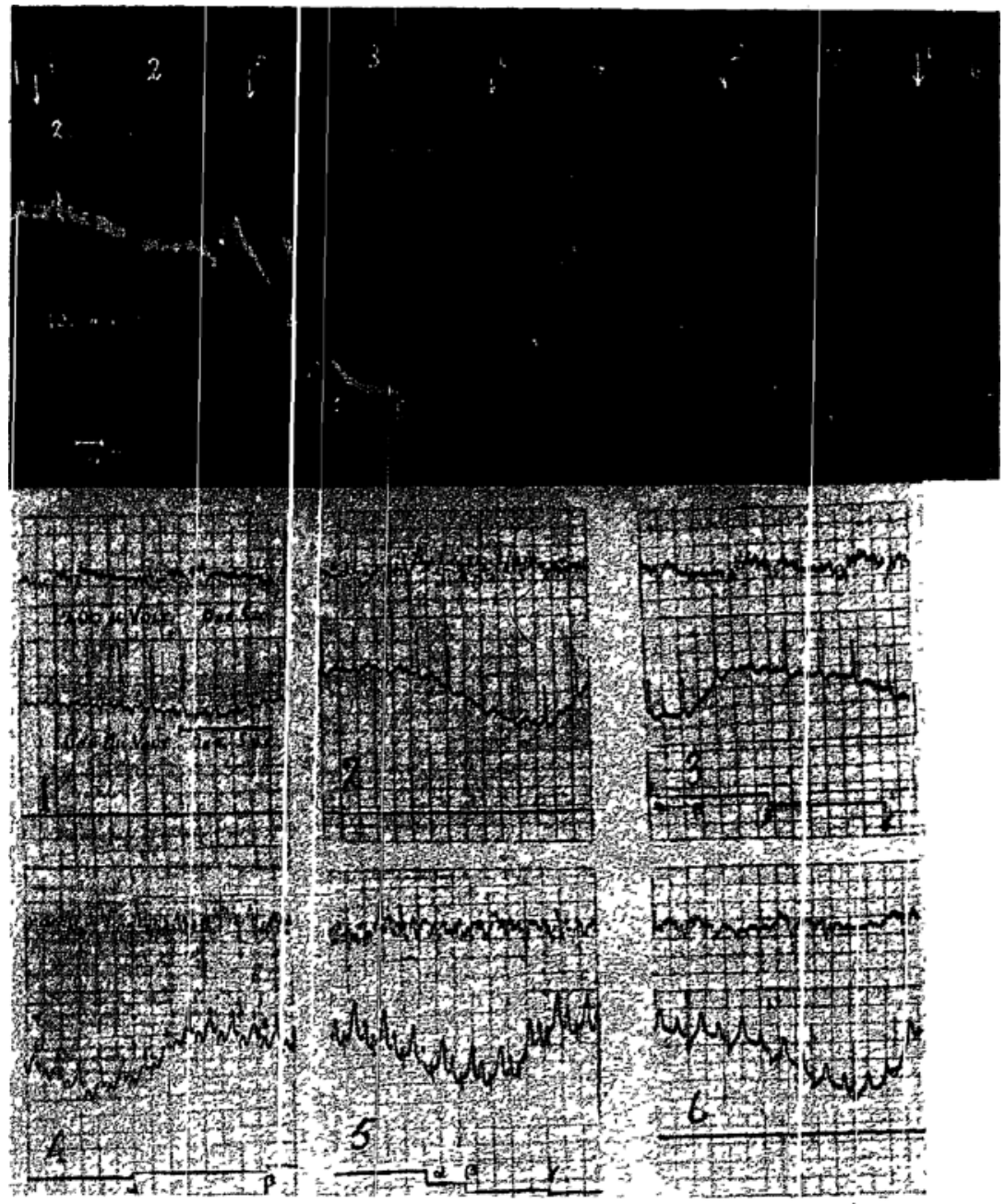

EXPERAMENT II

Experiment II. Dog, male, $8.2 \mathrm{~kg}$. Record of blood pressure (above) and associated sections of E.E G., E.C.G. and C.B.F. records (below), taken at nos. 1 to 6, as marked on the kymographic traaing, are shown. On nos. 3, 4, and 5 the changes correspond again to the points marked by $a, \beta, \gamma$, and $\sigma$. At $A$ and $C$, metrazol $(10 \mathrm{mg} / \mathrm{kg})$, at 8 , hexamethonium $(5 \mathrm{mg} . / \mathrm{kg}$.) at $\mathrm{D}$, chlorpromazine $(10 \mathrm{mg} / \mathrm{kg})$ and at $\mathrm{E}$, adrenalin $(200 \mu \mathrm{gm}$.) were injected.

As can be seen in Figure 6, following injection of picrotoxin (A), there is a progressive and sustained rise in blood pressure, associated with marked tachycardia and increased electrucal activity of the cortex (nos. 2 and 3). Injections of chlorpromazine at $\mathrm{B}$ and $\mathrm{C}$ led to the usual depressor response with tachycardia, although the E.E.G. showed a curious alternation of high and low voltage waves (nos. 4 and 5), suggestive of excessive cortical stimulation and subsequent repetition of picrotoxin (D) produced no further changes in the E.E.G. The results suggest that chlorpromazine does not prevent the cortical effects of picrotoxin.

When methamphetamine was injected at A and B (Fig. 7), although there was a more sustained pressor response the E.E.G. showed only a slight initial stimulaton followed by peculiar high voltage slow waves (no. 4). Following chlorpromazine (C) these waves still continued, although with reduced amplitude, but 

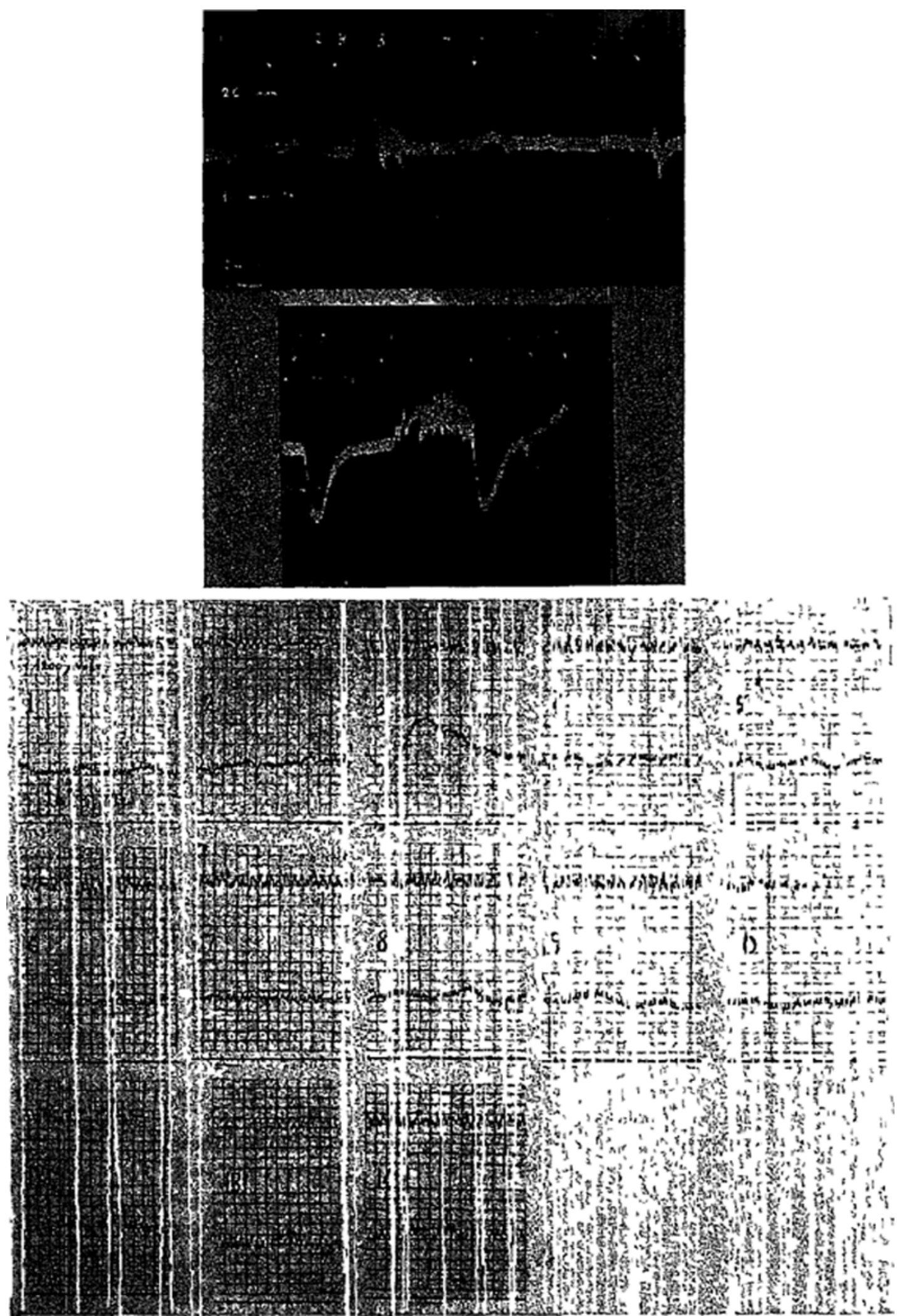
on repeated injection of methamphetamune ( $D$ and $E$ ) slow high voltage waves agan reappeared It $1 \mathrm{~s}$, therefore, clear that chlorpromazine does not block the cortical effects of methamphetamine It is of interest to note that although picrotoxin and methamphetamine are central nervous system stumulants, their effect on electrical activity as recorded is quite dufferent (compare Figs 6 and 7)

Finally, some experments were performed, in which chlorpromazine was ıxjected following previous administration of (a) ganghonic blockade, induced either by mection of ansolyen or hexamethonum, or $(\vec{b})$ peripheral sympathetzc blockude induced by hydergin Some ecamples of the results obtaned are shown in Figures 8 and 9

The most striking effects of the ganglionic blocking agents which were observed may be summarized as follows (a) There was no significant change in the pressor or $\mathrm{E} E \mathrm{G}$ responses to metrazol ( $\mathrm{F} 1 \mathrm{~g} \mathrm{8}$, upper and lower sections), and $(b)$ There was no sustamed depressor response or evidence of stumulated cortical electrical activity following repeated injectons of chlorpromazine

Following injection of the adrenergic blockmg agent (hydergm) alone, both the E E G outbursts and the pressor lesponses to mjected metrazol were, however, abohshed (Fig 9, upper section), but subsequent repeated injectaons of chlorpromazme agam led to nether the usual sustamed depressor responses nor the increased cortical activity Currously enough, whep the responses to metrazol were tested after both hydergyn and chlorpromazme, it is clear that both the usual E EG outbursts and the pressor responses were restored In additon, despite repeated chlorpromazine injections after hydergin the blood pressure was usually stll well mantamed and in some cases was higher at the end of the experiment than during the pre-injection control periods (see Fig 9, lower section ) It would, therefore, appear that the hydergin-metrazol combination completely antagonizes the prolonged depressor effects of chlorpromazıne, and associated with this action there was accentuation of the EEG outbursts induced by chlorpromazine This combunation might, therefore, be of some antdotal value following excessive chlorpromazne administrations, and would appear to warrant further investigation in ths connection

\section{Some Observations on the Effects of Diethazine (Diparcol)}

Diethazine is a close chemcal relative of chlorpromazine, and it was therefore of some interest to compare its effects with those of chlorpromazine under the conditions of these experments

In Figures 10 and 11 are 1llustrated some of the typical responses observed after repeated diethazine injections, and the influence of this agent upon the responses to metrazol As is evident from Figure 10, the de sressor responses to diethazme were much less sustained than those observed ater chlorpromazine

Figure 9 Dog, female, $75 \mathrm{~kg}$ (a) The upper and lower kymographic records are contunuous and associated sections of $(b)$ the E.E G and E C G taken at nos 1 to 14, as marked on the kymographuc tracungs, are shown At A, B, D, G and I, $5 \mathrm{mg}, 15 \mathrm{mg}, 10 \mathrm{mg}, 20 \mathrm{mg}$, and 10 $\mathrm{mg} / \mathrm{kg}$, respectively, of metrazol were injeated Hydergin $(03 \mathrm{mg} / \mathrm{kg})$ was given at $\mathrm{C}$ and $\mathrm{J}$, and chlorpromazine (10 mg $/ \mathrm{kg})$ at $\mathrm{F}$ and $\mathrm{H}$ 


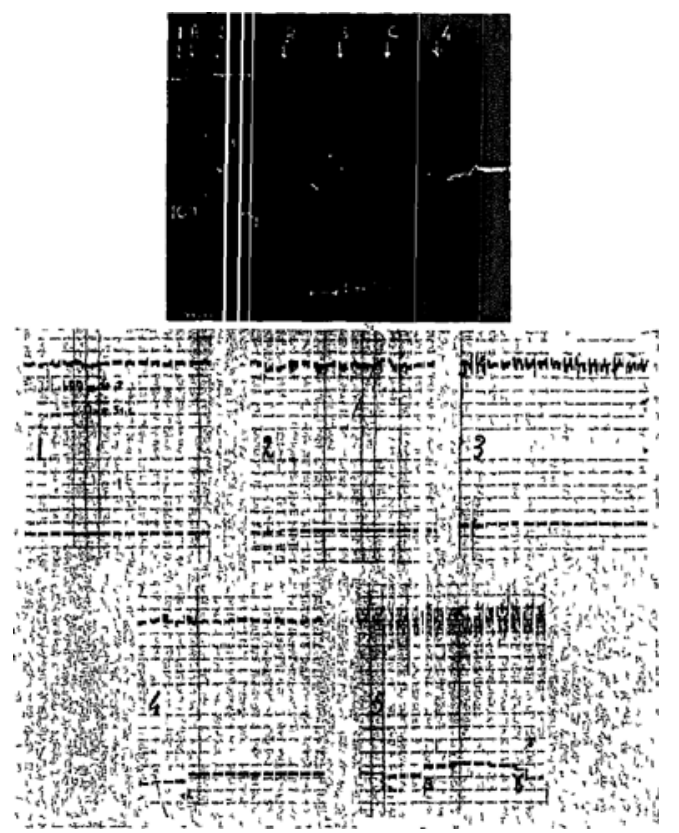

Figune $10 \mathrm{Dog}$, male, $170 \mathrm{~kg}$ Kymographic record of blood pressure (above) and sections of associated EEG, and ECG and CBF (below), taken at nos 1 to 4, as marked on the kymographe tracing, wre shown On No 2 the changes recorded correspond to the points marked by $a, \beta$ and $\gamma$ At $A(5 \mathrm{mg})$, and at $B$ and $C(10 \mathrm{mg} / \mathrm{kg})$ diethazane were injected

These effects were also associated with more untense cortical stumulation and increased cerebral blood flow (nos 3 and 4) In addition, both the central stumulation (EEG outbursts) and the pressor responses following metrazol, appeared to be potentated by diethazine, with concomitant augmented cerebral blood flow (Fig 11) However, following sympathetic blockade with hydergin, all of these effects are antagonized Thus, as can be seen from the records, both the usual pressor effect and cortical stmulation following metrazol are blocked However, whth supenmposed diethazine in such experiments, these responses to metrazol are again restored

It is also noteworthy that after injection of hydergin alone, the cerebral blood flow is decreased, despite the rise in blood pressure ( $17 \mathrm{gg} 12$, no 4) and subsequent in ections of metrazol or diethazine did not significantly restore the cerebral slood flow to normal although blood pressure agam was well man- 
tained From the above findings, it is clear that the over-all effects of diethazine were rather simular to those of chlorpromazine, except that they were less sustamed

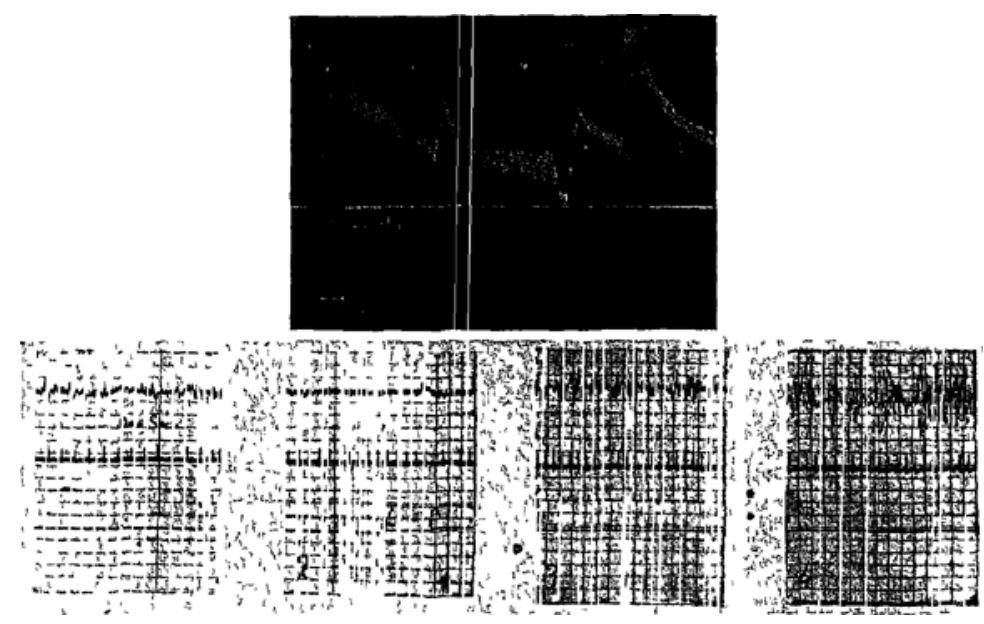

Figure 11 Dog, male, $96 \mathrm{~kg}$ Kymograplite record of blood pressure (above) and sectrons of associated E E G and C B F records (below), taken at nos 1 to 5, as marked on the kymographre tracing, are shown $O$ nos 4 and 5 the changes recorded correspond to the points marked by $\alpha, \beta$ and $\gamma$ At $A, B$ and $D$, metrazol ( $10 \mathrm{mg} / \mathrm{kg}$ ), and at $C$, diethazine $(5 \mathrm{mg} / \mathrm{kg}$ ) were injected

\section{Summiar AND CONCLUSIONS}

In curarized dogs under artuicial respiration, it was observed that $(a)$ chlorpromazine in high and repeated doses $(5$ to $20 \mathrm{mg} / \mathrm{kg}$ ) can mduce marked fall in blood pressure, tachycardia, and increased cerebral blood flow, $(b)$ prevous injections of similar high doses of chlorpromazne do not abolish either the pressor responses or cortical stimulation (outbursts) induced by metrazol, and both agents appear rather to lead to enhanced cortacal outbursts, $(c)$ chlorpromazine also does not affect the cortcal stumulation (E E G changes) following injections of nkethamide, picrotoxin, or amphetamme, but antagonizes the blood pressure responses to these agents, (d) after ganglionic-blockade (ansolysen or hexamethonuum) cortical changes induced by chlorpromazine are not prevented, but its depressor response is lessened by ansolysen, but on the contrary enhanced by hexamethonum, (e) after sympathetic blockade (hydergan) both the central stimulation and pressor responses to metrazol are prevented, but the depressor response to chlorpromazue is antagonized and combuned hyderginmetrazol treatment appears to prevent the usually observed depressor effects of 

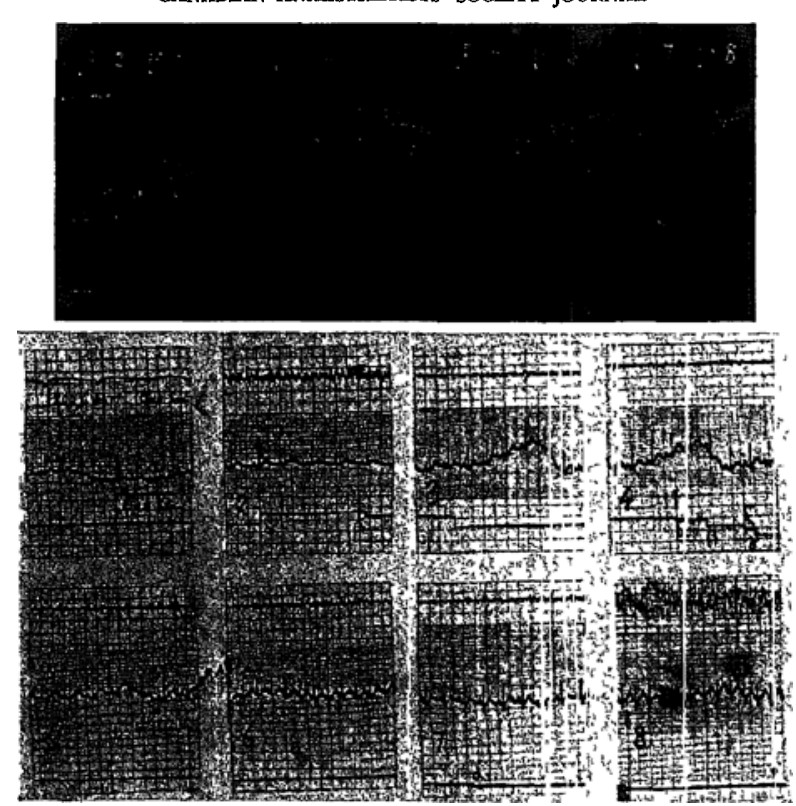

Figure 12 Dog, male, $74 \mathrm{~kg}$ Kymographic record of blood pressure (above), and sections of associated E EG, E CG, and $\mathrm{CBF}$ records (below), taken at nos 1 to 8 , as marked on the kymographuc tracung, are shown On nos 2, 4 and 7 the changes recorded correspond to the points marked $a_{1} \beta$ and $\gamma$ At $A, D, E$ and $G$, metrazol $(10 \mathrm{mg} / \mathrm{kg})$ at $B$, diethazine $(5$ $\mathrm{mg} / \mathrm{kg})$, at $\mathrm{C}$, hydergın ( $1 \mathrm{mg} / \mathrm{kg}$ ) and at $\mathrm{F}$, dethazinc $(5 \mathrm{mg} / \mathrm{hg})$ were injected

excessive chlorpromazme injections, and $(f)$ diethazine appears to exert simllar actions to those of chlorpromazme, but its effects are less sustamed

\section{RÉSUMÉ}

Chez des chiens curansés placés sous respiration artificielle, on a observé certaines réactions à savorr que (a) la chlorpromazme à hautes doses répétées ( 5 à $20 \mathrm{mg} / \mathrm{kg}$ ) peut produre une chute marquée de la pression sanguine, une tachycardie et une augmentation de l'aftlux sangun au niveau du cerveau, $(b)$ les injections antérieures de telles doses elevées de chlorpromazine nabolıssent $\mathbf{m}$ l'effect sur la pression nu la stımulatıon du cortex causés par le metrazol, les deux agents semblent plutôt produre des réactons électriques soudanes et violentes dans le cortex, (c) la chlorpromazıne n'affecte pas la stımulation corticale, à la surte d'injections sout de coramine ou de picrotoxine ou de amphetamme, mass empêche les réponses de la pression sanguine à ces agents, $(d)$ dprès un blocage 
ganghonıarre (ansolysen ou hexamethonuum) on ne prévent pas les changements cortrcaux apportés par la chlorpromazine, et l'effet depresseur est dimunué par "ansolysen alors qu'll est augmenté par l'hexamethonum, $(e)$ après un blocage jympathque (hydergne) la stumulation centrale et l'effet sur la pression causés jar le metrazol sont nuls L'effet dépres'eur de la chlorpromazıne sur la crrculaton sangune est inversé et le tratement à l'hydergine associé au metrazol semble prévenir cet effet dépresseur habituellement observé à la sute des injections de dosês excessives de chlorpromazıne, et qu'enfin, la diethazıne semble produre les mêmes réactions que la chlorpromaz me mass avec des effets qux sont moins soutenus

\section{REFERENCES}

1 Lerrians, H E Therapeutic Results whth Chlorpromazine in Psychratrie Conditions Ganad M A J 7291 (1955)

2 Das, N N, Dasgupta, B R, \& Wenner, G The Effect of Chiorpromazine on the Electrical Activity of the "Cerveau ssolé" Arch $f$ exper Path u Pharmakol 224248 (1955)

3 Schuichthen, W, Bustow, M E, SchuLtz, S \& Henderson A L Sezzures occurning durng Intensive Chlorpromazine Therapy Canad M A J 74. 364 (1956)

4 Largactil Poisoning Brit M J 16204956 (Dec 21, 1955)

5 Preston, J B Effects of Chlorpromazine on the C N S of the Cat A Possible Neural Basus for Its Action J Pharmacol \& Exper Therap 118100 (1956)

6 Berige, F M, Campaeld, G L, Hende Action of Tranquilizers on Braw Potentials and Serotin, in The Pharmacology of Psychotherapic Drugs Ann New York Acad Se 66 688 (1957)

7 Marcolis, L H Phamacotherapy in Psychuatry A Revew in The Pharmacology of Psychotherapke Drugs Ann New York tcad Sc 66 698 (1957)

8 Winkeliman, $N$ W Chlorpromazine in the Treatment of Neuropsychiatric Disorders J A M A 15518 (1954)

9 Golman, D Treatment of Psychotic States with Chlorpromazine JAMA $157 \quad 1274$ (1955)

10 Krliy, R E, \& Lawnence D R Effects of Chlorpromazane on Convulsions of Expenmental and Clnncal Tetanus Lancet, p 118 (Jan 21, 1950)

11 Thimatrit, M C Un cas d'état de mal épuleptuque post-operatore grave tranté par hubernution artifictelle Anesth \& Analg 12418 (1955)

12 Lemmans, H E, \& Hanraiman, G E Chlorpromazine' New Imbrbitng Agent for Psychomotor Excitement and Manc States Arch Neurol \& Psychat 71227 (1954)

13 Meivirle, K I Studies on the Cardiovascular Actuons of Chlorpromazine I Antadrenergic and Antefibrillatory Actons Arch internat de pharmoçodyn et de therap (1958)

14 Melville, K I. \& Drapeau, J Studies on the Cardiovascular Actions of Chlorpromazine II Effects on Carduac Output, Coronary Flow and Heart Contractions Arch mternat de pharmacodyn et de thérap (in press)

15 Ludwics, N Ueber ene Modifikation der Methode nach Gibbs zur lokaliserten Durchblutungsmessung des Hirngewebes und die Gultgkeit der damit erhobenen Hefunde Pllugers Archiv 25935 (1964)

16 Jenkner, J L, \& Lechnek, H The $\mathrm{F}$ ffect of Diparcol on the $\mathrm{E} E \mathrm{E}$ G, in the NormaI Subject and in Those with Cerebral Trauma E E G Cln Neurophysiol 7303 (1955) 